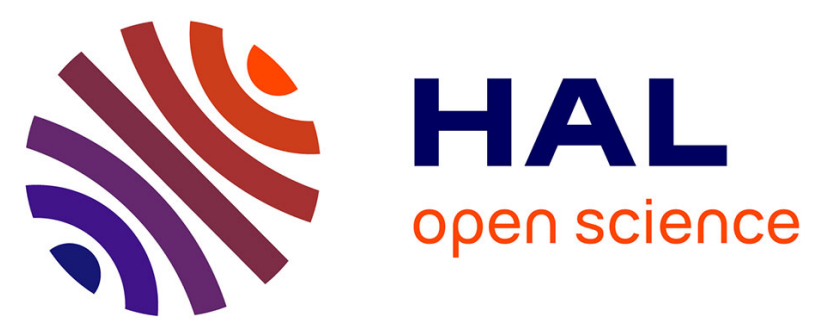

\title{
Groundwater Management Planning at the River Basin District Level: Comparative Analysis of the Adour-Garonne and Loire-Bretagne River Basins
}

\author{
Jean-Daniel Rinaudo, Pierre Marchet, Pascal Billault
}

\section{To cite this version:}

Jean-Daniel Rinaudo, Pierre Marchet, Pascal Billault. Groundwater Management Planning at the River Basin District Level: Comparative Analysis of the Adour-Garonne and Loire-Bretagne River Basins. Sustainable groundwater management: a comparative analysis of French and Australian policies and implications to other countrie, pp.67-91, 2020, 10.1007/978-3-030-32766-8_4 . hal-02532156

\author{
HAL Id: hal-02532156 \\ https://hal.science/hal-02532156
}

Submitted on 15 Apr 2020

HAL is a multi-disciplinary open access archive for the deposit and dissemination of scientific research documents, whether they are published or not. The documents may come from teaching and research institutions in France or abroad, or from public or private research centers.
L'archive ouverte pluridisciplinaire HAL, est destinée au dépôt et à la diffusion de documents scientifiques de niveau recherche, publiés ou non, émanant des établissements d'enseignement et de recherche français ou étrangers, des laboratoires publics ou privés. 


\title{
Chapter 4. Groundwater management planning at the river basin district level: comparative analysis of the Adour-Garonne and Loire- Bretagne river basins
}

\author{
Jean-Daniel Rinaudo ${ }^{1}$, Pierre Marchet ${ }^{2}$, Pascal Billault ${ }^{3}$, \\ 1 BRGM (French Geological Survey), Montpellier University, Montpellier, \\ France \\ ${ }^{2}$ Agence de l'Eau Adour Garonne, Toulouse, France \\ ${ }^{3}$ Agence de l'Eau Loire Bretagne, Orléans, France \\ Corresponding author: jd.rinaudo@brgm.fr
}

\begin{abstract}
In France, water resource management issues are addressed in the framework of local plans (SAGE) and strategic master plans for managing river basins (SDAGE). This chapter describes how strategic blueprints are formulated and implemented. It focuses on quantitative groundwater management issues and the legal and regulatory framework which defines planning objectives and practices. In addition, there is an historical analysis of 20 years of groundwater planning in the Adour-Garonne and Loire-Bretagne river basin districts.
\end{abstract}

Keywords: river basin; plan; water agency.

\section{Introduction}

Since the beginning of the 1990's, French policy makers have increasingly recognized the need to better integrate the different aspects of groundwater and surface water management, and the protection of aquatic habitat and ecosystems (Piegeay et al, 2002). This integration has progressively been achieved through the development of Water Development and Management Master Plans, called Schéma Directeurs de Gestion et d'Aménagement des Eaux (SDAGE) in French. Established for each of the six major river basin districts (see Figure 4. 1), these blueprints outline how to implement the national legal and regulatory framework in operational 
terms. The SDAGE takes into account all surface water environments (watercourses, canals, bodies of water and so-called transitional coastal and brackish waters) and groundwater (confined and unconfined aquifers). It deals with the problems relating to quantitative management, pollution, the ecological quality of aquatic habitats, as well as issues of flooding. It also tackles broader issues, such as the governance, organisation and dissemination of data relating to water.

This chapter describes how the SDAGEs have taken groundwater into account, by examining the case study of the Adour-Garonne and Loire-Bretagne river basin districts. The first section examines water management planning in France in a historical context, while the second section presents the main characteristics of the Adour-Garonne and Loire-Bretagne river basins and focuses on the mechanisms involved in quantitative groundwater management. The water management plans are studied in sections 3 and 4 . The conclusion compares the two examples and proposes several recommendations drawn from over 20 years of experience in the two river basins studied.

\section{The French approach to water management planning}

\subsection{The creation of river basin agencies (1964)}

Water management planning on the scale of the major river basins was introduced in France by the 1964 Water Act, which was reinforced by the 1992 law. Inspired by the model implemented in the Ruhr in Germany (Barraqué et al, 2018), the 1964 law created six large river basin agencies (Figure 4. 1). Their mission was to promote the joint and cohesive management of water resources, based on three main principles: (i) an integrated approach to all issues of water management (irrigation, sanitation, drinking water, aquatic environments and flooding); (ii) a sharing of financial resources at the river basin level to protect or restore water resources; and (iii) the participation of representatives of water users in management decisions. Unlike similar institutions established in Germany, Holland or Spain, the water agencies are not directly involved in the creation or operational management of infrastructure. 


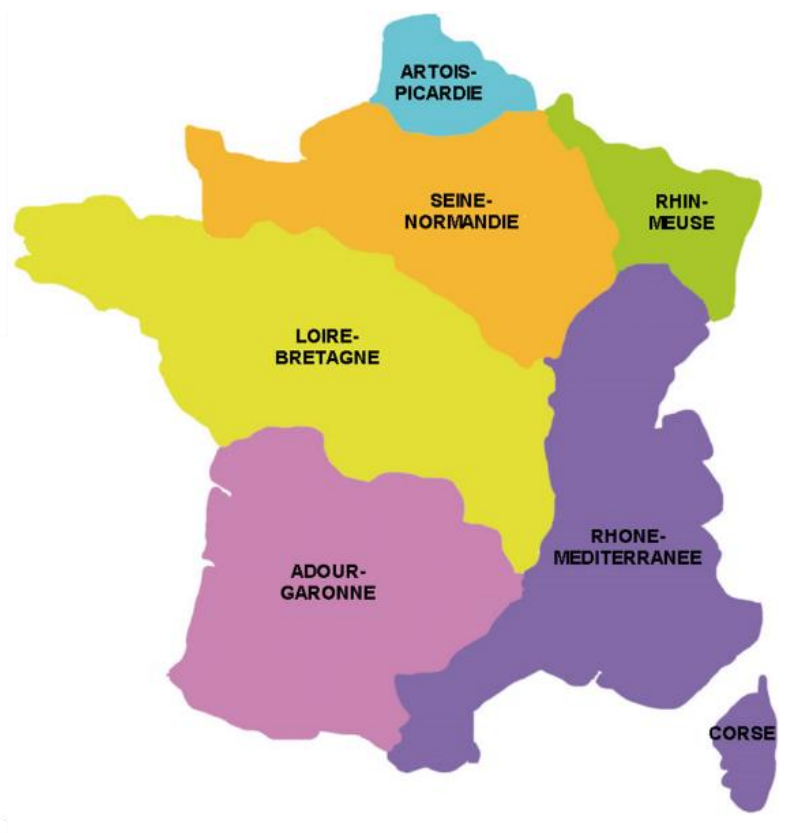

Figure 4. 1: Regions covered by the six water agencies in metropolitan France.

The 1964 water law authorised the river basin agencies to collect a fee from water users. The fee is proportional to the quantity of water abstracted and/or the quantity of pollution discharged and all the revenue raised is used to support projects (in the form of a grant or an interest-free loan), which aim to improve the state of water resources. The projects may be run by public or private stakeholders. Once established, the agencies operate as "mutual savings banks" for water users (Barraqué et al, 2018). The budget allocation for each agency is based on a five year plan drawn up by the river basin committee which defines the priorities for action and the corresponding budget allocations. The committee is composed of equal numbers from three groups; water user representatives, mayors and local councillors and officials from the state agencies. The fees are set by the agencies' board of directors where the state has the majority, and then approved by the river basin committee ${ }^{13}$. Today, $85 \%$ of the revenue comes from fees paid by domestic users. The overall budget managed by the six agencies amounts to 1.8 billion euros per year (Roche, Guerber, et al., 2016). The amount allocated to the quantitative management of surface and groundwater resources only represents $6.5 \%$ of the budget (Table 4.1 ).

${ }^{13}$ As the fees were considered to be tax levies, parliament has directed the agencies' budget and capped their expenditure since 2006. 
Table 4. 1: Breakdown of subsidies granted by the six water agencies

\begin{tabular}{|l|c|} 
Water management issue & $\begin{array}{c}\text { Budget share } \\
\text { \% }\end{array}$ \\
\hline Urban domestic wastewater treatment & 55.8 \\
\hline Drinking water supply & 8.4 \\
\hline Policy implementation & 6.8 \\
\hline Industrial pollution control & 5.7 \\
\hline $\begin{array}{l}\text { Restoring the quality of aquatic environ- } \\
\text { ments }\end{array}$ & 10.3 \\
\hline Agricultural pollution control & 6.5 \\
\hline Quantitative water resource management & 6.5 \\
\hline
\end{tabular}

http://www.lesagencesdeleau.fr/en/les-agences-de-leau/les-leviers-daction-des-agences-deleau/ (consulted 10/10/2018)

\subsection{The introduction of management plans (1992)}

The 1992 Water Act consolidated the role of the river basin agencies by significantly strengthening their powers with regard to water management planning and making them responsible for preparing the Water Development and Management Master Plans. The aim of these blueprints was to build a joint action framework for all the water stakeholders in the river basin in order to restore and maintain the good status of the water resources and aquatic habitats (which are considered to be a common heritage), with a view to providing a long term guarantee for all uses. In addition to the financial planning mission assigned to the agencies by the 1964 law, they were also given a technical planning mission. The SDAGE converts the sectorial public policy guidelines and the European directives into coherent, operational and localised action, by concentrating resources on priority objectives. The first SDAGEs were approved in 1996.

The SDAGEs have a legal standing similar to urban planning documents. They are legally binding for the administration, which means that all decisions taken by public administrations must comply with the provisions set out in the SDAGE. Thus, they direct the action of numerous other administrations involved in local water management. They also define coherent units for the water basins, which provide the basis for the future Local Water Management Plans (Schémas d'Aménagement et de Gestion des Eaux or SAGE in French).

The SDAGE sets out provisions, recommendations and reminders. The provisions correspond to the river basin committee's major goals or main priorities, while 
the recommendations concern the partners and act as incentives. Lastly, the reminders highlight the legislation or regulations related to water management issues addressed in the plan

The SDAGE's broad guidelines are deployed on a local level within the framework of the local water management plans, the SAGEs. Each SAGE is developed at the scale of sub-basins, aquifers, lakes, etc and its boundaries usually does not correspond to administrative boundaries. Some SAGEs, such as the Beauce Aquifer SAGE (see Chapter 4), straddle two agencies, several regions and several counties. The SAGE carries out an initial assessment of water and environmental conditions, sets goals for the use and development of the resources and the aquatic environments, identifies the priority actions to achieve the targets and assesses the technical and financial resources. The SAGE establishes operational management rules that are legally binding for the administration following the 1992 Water Act. In 2006, the rules defined by the SAGE also became legally binding for third parties. The SAGE is established by a local water commission composed of local councillors, user representatives and state service officials, and is approved by the state after verifying that it is consistent with the provisions of the SDAGE.

With regard quantitative groundwater management, all the groundwater pumping authorisations granted to users must be compatible with the provisions set out in the SDAGE and the SAGE. The latter can limit the total volume allocated, for example. Similarly, the SDAGE and/or the SAGE restrict total use and set groundwater level thresholds that trigger prohibitions if they are exceeded. Chapters 4 and 11 present good examples of SAGEs that were established to ensure sustainable groundwater resource management. 


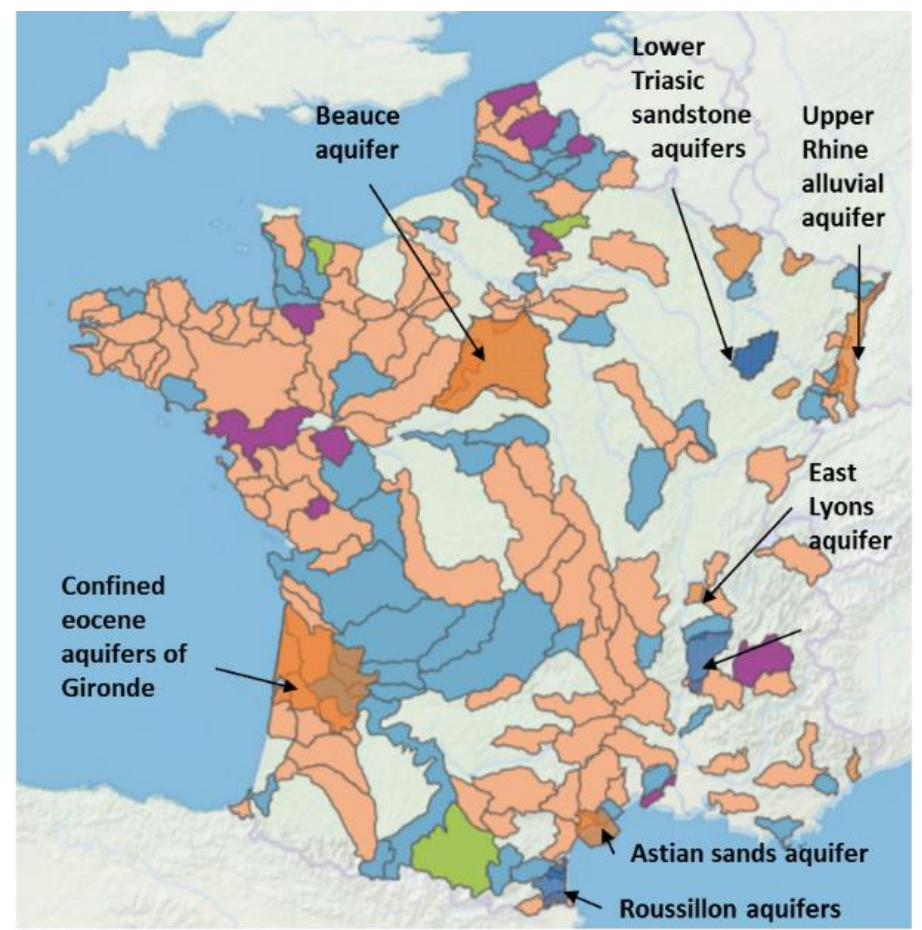

Names indicate SAGE focussing on groundwater management

Preliminary step

Plan under development

Plan approved and implemented

Under revision (preparation of $2^{\text {nd }}$ version)

(source www.gestau.fr/sage. 11/2017)

\section{Figure 4. 2: Map of local water management plans in France}

\subsection{Planning, a new European obligation}

The European Water Framework Directive (WFD) adopted in 2000 strengthens the planning objectives at the river basin level. The WFD imposes several principles already applied in France:

1) it promotes an integrated approach of water management issues relating to quality, quantity and the ecological quality of habitats;

2) planning must be formalised with the joint development of a management plan (the SDAGE in France) with a corresponding programme of 
measures describing the practical actions to be implemented over a six year period;

3) the programme of measures must be scaled in order to guarantee that the environmental goals set out in the management plan are achieved (performance requirement) by 2015 (with the option of a 6 to 12 year additional delay);

4) the programme of measures and the management plan are established with the stakeholders' involvement and in consultation with the public; and

5) the programme of measures is subject to an economic assessment (Laurans et al, 2001).

After the WFD came into force, the river basin committee remained the body responsible for preparing the SDAGE. It relied on thematic or geographic commissions, made up of members of the river basin committee and invited outside experts. The technical secretariat was generally managed by the water agency and the regional administration (DREAL) which represents the Ministry of Ecology. Technical and scientific studies are either conducted by the agency's teams or assigned to consultancies or research organisations. The programme of measures is established by the state services, under the authority of the prefect (government official), who coordinates the basin.

On a technical level, the WFD also modified the SDAGE's content. It imposed performing an in-depth appraisal of the initial situation, which went further than the appraisal conducted by the SDAGE in 1996. This initial appraisal was conducted systematically using a new hydrogeological breakdown based on the groundwater bodies. The multi-layered confined aquifers were divided vertically (Brugeron et al, 2013; EC, 2004). For each water body, the assessment summarised its characteristics, hydrogeological function, as well as its qualitative and quantitative status. The appraisal identified bodies of water with a poor status (quantitative or qualitative), which needed to be remedied by the provisions in the programme of measures. According to the WFD, a water body has a good quantitative status if "the level of groundwater in the body of water is such that the average annual abstraction rate in the long term does not exceed the available resource in the groundwater body".

When it comes to monitoring the status of groundwater bodies, the WFD requires member states to set up several monitoring networks, which include two main networks. The surveillance network is designed to provide an overview of the general state of water at a European level. The operational control network is geared to monitoring the bodies of water unlikely to meet the good status target (see chapter 9), and has additional stations in problematic zones. The operational controls cease when the body of water achieves a satisfactory status. Quantitative groundwater monitoring is based on stations that monitor groundwater levels (piezometers), spring flow and the flow of watercourses which depend on baseflow from aquifers. 
The SDAGE is a document that results from extensive consultation with local councillors, state officials and user representatives. It is the outcome of several years of consultation involving the river basin committee's thematic and geographic commissions, discussions with water stakeholders, consultations with the regional and county assemblies, as well as a consultation with local residents in the river basin. Priority actions identified in the SDAGE reflect a compromise that was reached by the stakeholders involved in preparing the document. The approval of the SDAGE is subject to a vote by the river basin committee (absolute majority required) before being jointly signed by the prefect of the river basin representing the state, and the president of the river basin committee.

The following two sections describe how the planning process described above was implemented in the Adour-Garonne and Loire-Bretagne river basins. They present the content of the SDAGEs and how they evolved over the period from 1996 to 2018. The two river basins are characterised by intense groundwater use and problems of quantitative management which are more serious than elsewhere in France. In both cases, the main resources developed are deep confined aquifers in the Aquitaine and Parisian sedimentary basins and the alluvial aquifers associated with major watercourses (see Chapter 2). Table 4.2 below shows some data relating to the water uses in these river basins.

Table 4. 2: Main characteristics of the Adour-Garonne and Loire-Bretagne river basins

\begin{tabular}{lll}
\hline & Adour-Garonne & Loire-Bretagne \\
\hline Population & 7 million & 13 million \\
\hline $\begin{array}{c}\text { Agriculture } \\
\text { (cultivated area) }\end{array}$ & $116000 \mathrm{ha}$ & $155000 \mathrm{ha}$ \\
\hline Volume abstracted & & \\
- for irrigation & $1000 \mathrm{M} \mathrm{m}^{3}$ & $500 \mathrm{M} \mathrm{m}^{3}$ \\
- for drinking water & $2000 \mathrm{M} \mathrm{m}^{3}$ & $1000 \mathrm{M} \mathrm{m}^{3}$ \\
\hline
\end{tabular}

\section{Groundwater management planning in the Adour-Garonne Basin}

\subsection{The emergence of the "groundwater" problem}

At the end of the 1980s, the Adour-Garonne Water Agency acted primarily as a funding body for the water sector. It was organised into two main departments; one 
that managed issues related to water resources and the drinking water supply and the other that was involved with industrial and urban wastewater treatment. Each department independently planned their programs which were largely based on financial considerations. In the early 1990s, an agency-wide planning group was created which included a few specialists and was supervised by the agency's directors. By the end of the 1990s, this group had expanded to a large team.

At the time, diffuse groundwater pollution was not yet considered to be a serious problem. The question of nitrates was tackled by a national committee (named CORPEN) and pesticides were not recognised as an issue. Therefore the agency focused on quantitative management issues and above all, the construction of water storage facilities which it subsidised heavily. This program was implemented under the framework of the 10-year plan for water resource management (the Plan Décennal de Gestion des Ressources en Eau or PDRE in French). The plan's overall aim was to build reservoirs with a total capacity of 1 billion $\mathrm{m}^{3}$, through a combination of large dams (like the Charlas project with a capacity of 110 million $\mathrm{m}^{3}$ ), collective hill reservoirs and small individual reservoirs. The PDRE's goal was to sustain river flow during dry weather periods to compensate for the impacts of abstraction for irrigation purposes, which increased in the late 1980s. The 10-year plan did not include any action linked to groundwater. At the time, the groundwater resource did not seem capable of meeting the challenge of providing 1 billion $\mathrm{m}^{3}$. Alternative solutions such as artificial groundwater recharge or water saving programs, had not yet been considered.

At the time, the Adour-Garonne Water Agency did not have an overall vision of the issues of groundwater management in the river basin. However there were some local initiatives, for example in the Gironde region, where stakeholders were involved in developing a management system for the deep aquifers (see Chapter 12.). These initiatives made the agency aware of the need to examine the issues of groundwater management in the river basin before developing a strategy. This mission was assigned to one of the agency's hydrogeologists, Michel Plaud (Plaud, 1996), who spent two years working with the French Geological Survey (Bureau de Recherches Géologiques et Minières). The resulting inventory was made up of five regional assessments and provided a scientific basis for the discussion between stakeholders at the river basin level, as well as nationally (Martin, 1996).

When the preparation of the first SDAGE began, the river basin committee set up seven regional commissions responsible for identifying major water management issues and formulating strategic proposals to deal with them. The river basin committee was aware that tackling the problems relating to the confined aquifers was no easy matter, especially since they are extensive in area and often located beneath regions managed by several commissions. As a result, it created an eighth commission responsible for managing the confined aquifers in the Aquitaine Basin. The commission produced a report in the form of a "geographic notebook", which focuses on the deep confined aquifers. The associated problems were already apparent because they concerned the drinking water supply for Bordeaux. The analysis 
conducted by the seven other territorial commissions barely mentioned groundwater. There were particularly large gaps in the knowledge about agricultural usage volumes, which meant that the analysis was not very relevant.

\subsection{Groundwater in the first SDAGE (1996)}

The 1996 SDAGE was organised around six water management issues: A) Management and protection of coastal and aquatic environments; B) Qualitative resource management; C) Quantitative resource management; D) Flood control; E) Organising and managing information relating to water; and F) Organising integrated management. The measures relating to groundwater management are essentially found in $\mathrm{C}, \mathrm{E}$ and $\mathrm{F}$.

In terms of quantitative management, which is the subject covered in this chap$\operatorname{ter}^{14}$, the SDAGE mainly highlighted the issues linked to the deep aquifers. In particular, it identified the threat of salt water intrusion in the confined aquifers near the coast or estuary (the Eocene aquifer in the Gironde), which was caused by the intensity and concentration of groundwater pumping. It also highlighted the limited understanding of groundwater due to the inadequate groundwater monitoring network.

The SDAGE's three main provisions regarding groundwater were the following (Figure 4. 3). Firstly, it defined the outlines of a technical and institutional management scheme for ensuring sustainable groundwater extraction; this model was intended to guide the development of local water management plans (SAGE). Secondly, it encouraged the production of consistent scientific information about the groundwater resources and its dissemination. Finally, it established a Commission responsible for coordinating groundwater management actions at the basin level. These three main provision were translated into 10 operational proposals for action (measures) that provided the foundations for a groundwater management strategy (see Table 4. 3). These measures were essential because they determined what programs the agency could help finance, and also provided a regulatory framework which directed the actions of the public agencies, as well as the stakeholders responsible for developing local water management plans.

${ }^{14}$ The SDAGE identified nitrate pollution in the aquifers as a major concern (p22). 


\section{SDAGE 1996}

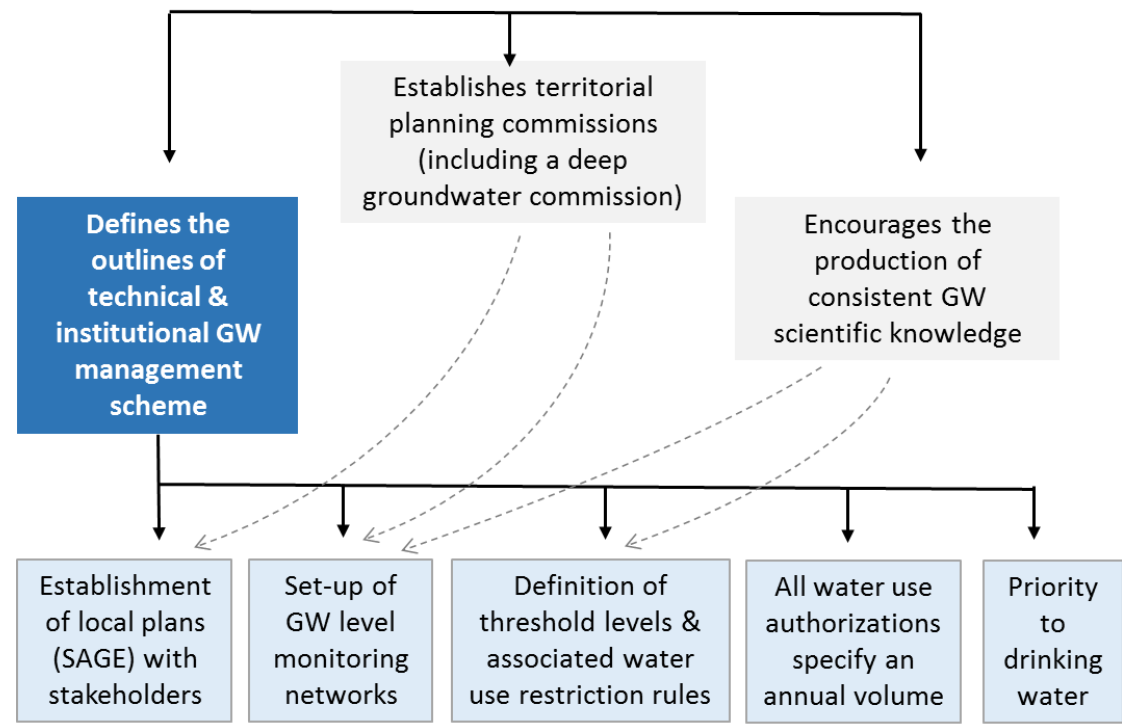

Figure 4. 3: Main provisions in the first Adour-Garonne SDAGE (1996). 
Code Measure description

C17 Groundwater, particularly when abstracted from confined aquifer, should be used as a priority for drinking water supply, then thermal activities and finally agriculture and industry. This priority ranking should be observed by State agencies when delivering abstraction permits. They should also be reasserted in all SAGEs.

C18 For each major aquifer, water level monitoring points should be defined. Target and Crisis threshold water levels should be defined for each of these points. A definition of TTL and TCL is given in the text.

C19 The state, the relevant regional authorities and the water agency should jointly develop a common network of monitoring stations for the main aquifer systems. Areas where monitoring network should be deployed in priority are listed.

C20 Water extraction regulation rules should be specified and implemented in a number of aquifers (listed) in the two years that follow the publication of the SDAGE. These rules aim at ensuring that TTLs are respected. Water restrictions rules are implemented if necessary.

C22 The SAGE can further elaborate GW management rules. They can in particular, define TTL/TCLs as well as water use restriction rules. They should as much as possible account for interactions between surface and groundwater resources.

C23 County and regional councils are encouraged to contribute to the collection and dissemination of groundwater data and information.

C27 All water abstraction licences granted by government administration should specify maximum authorized flow rate and volume.

B25 To undertake an inventory of aquifers representing a strategic interest for current and future water supplies and to define of programme of actions to protect those aquifers

E11 Research programs likely to contribute to the objectives of the SDAGE should be financially supported. A list of research themes is provided in the text.

F4 The Territorial Commission in charge of deep groundwater management issues should establish a stakeholder platform for developing a global strategy and common governance for all the confined aquifers. 
This platform prepares decisions of the River Basin Committee concerning deep aquifers. It identifies studies that should be conducted.

\section{Table 4. 3: Measures for groundwater quantitative management in the 1996 Adour-Garonne SDAGE}

The groundwater management scheme proposed in the SDAGE relies on three pillars: the identification of monitoring points that will be used to assess the state of each resource and to monitor any changes over time; the definition of sustainable groundwater threshold levels that should be maintained over time; and the design of rules of use ensuring that abstraction remains compatible with the water level objectives.

For each monitoring site, the SDAGE (measures C18 and C20) required defining two types of threshold associated with these sites: a target threshold level (TTL) and a crisis threshold level (CTL). The target level is the groundwater level above which all uses can coexist normally while maintaining a satisfactory state of the aquifers and dependent ecosystems. The State should subsequently manage the allocation of abstraction licences in such a way that this threshold is not breached. The crisis threshold is the groundwater level that should never be exceeded. Its aim is to prevent the occurrence of major adverse impacts on the groundwater resource (e.g. the risk of salt water intrusion and contamination of shallower aquifers), the drinking water supply, or aquatic environments dependent on groundwater. If the crisis threshold is exceeded, the State gradually implements a series of measures ranging from restricting the timing of extractions, to a possible total pumping ban.

The TTL and CTL values can be set in the SDAGE for the main aquifer systems. The TTLs in confined aquifers are set to ensure that the aquifers remain confined and do not under any circumstances, allow inflow of lower quality water from other sources. The TTLs for coastal aquifers are set to prevent saline water intrusion and are based on the level that corresponds to the highest tides. Lastly, TTLs can be fixed for unconfined shallow aquifers where they significantly contribute to the recharge of deeper aquifers. To monitor groundwater levels, the SDAGE recommends that the state, the relevant regional authorities and the water agency jointly develop a common network of monitoring stations for the main aquifer systems (measure C19). The SDAGE identifies priority zones for developing the networks.

With regard to water abstraction regulation, the SDAGE recommended that rules be established for the all priority confined aquifers in the two years following its approval (measure C20). These rules could be more precisely defined at a local level during the preparation of the local plans (SAGEs) with input from stakeholders. The SDAGE also required that the abstraction permits granted by the state specify a maximum volume for abstraction for each well or borehole (measure C27). Thus, it laid the foundations for volumetric management which was not imposed explicitly by the water law. The SDAGE also confirmed that the use of groundwater for drinking water was a priority (measure $\mathrm{C} 17$ ). This priority should be taken into account 
when the state services deliver administrative authorisations for abstraction. A complementary measure recommends conducting an inventory of the aquifer systems of strategic interest at the river basin level, for the current and future drinking water supply (measure B25).

A key element in the 1996 SDAGE groundwater strategy was to encourage cooperation between the participants. The county councils and the regional councils were invited to take part in the collection and dissemination of the data required for collective groundwater management. They were also invited to participate in information and awareness-raising programs targeting different audiences (including the general public), with the aim of improving the understanding of how the groundwater systems function and the related issues requiring management (measure C23). This resulted in the development of several regional web based information systems for groundwater management (SIGES - Systèmes d'Information pour la Gestion des Eaux Souterraines in French). The SDAGE also identified strategic aquifers for current and future drinking water supply, which should be studied as a priority. Lastly, the SDAGE required the deep aquifer commission to coordinate and develop a global strategy for all the confined aquifers within the basin, with the implicit aim of developing a global approach to governance for the deep aquifers.

Overall, the 1996 SDAGE provided the impetus for a developing a coherent groundwater policy for the Adour-Garonne Basin, in close consultation with representatives from the state and user groups. Its main limitation was that it gave almost total priority to the deep groundwater in the Gironde, with no mention of the real problems that affected the confined and unconfined aquifers in the sedimentary region of Poitou-Charentes-Dordogne or the major unconfined alluvial aquifers (Conseil Scientifique, 1999). This approach can be explained by the economic importance of the Gironde deep aquifers, but also by the fact that they had been the focus of studies and management endeavours for 20 years. To compensate for this shortfall, the state was forced to adopt unilateral measures prohibiting the construction of any new boreholes in the aquifers not covered by the SDAGE (except boreholes used for supplying drinking water).

\subsection{The revisions of the SDAGE from 2010 to 2016}

The 1996 SDAGE for the Adour-Garonne Basin was updated in 2010 and again in 2016. Overall, the management strategy defined in the 1996 SDAGE was consolidated, with the recommended measures focussing on the issues which were not sufficiently covered in the first version. The SDAGE was also adapted to meet the requirements of the European Water Framework Directive.

The 2010 SDAGE stated that groundwater resources constitute an extremely important natural heritage for the river basin for two main reasons. Firstly, they significantly contribute to ensuring the good ecological conditions of rivers and dependent ecosystems (e.g. link between wetlands and the alluvial aquifers). Secondly, they make up a large proportion of the strategic resources for supplying 
drinking water today and in the future. Therefore, they should be protected and developed to supply drinking water as a priority. To achieve this, the 2010 SDAGE emphasised the need to improve our understanding of the interactions between surface and groundwater in particular (measure $\mathrm{C} 1$ and E10). It also recommended developing decision-making and modelling tools (measure C3) and conducting forecasts in order to anticipate the effects of climate change to facilitate adaptation (measure E12).

Unlike the 1996 SDAGE, which focused mainly on the confined aquifers, the 2010 SDAGE also dealt in depth with the problems of managing unconfined aquifers. A new assessment distinguished 105 groundwater bodies, including 20 confined aquifers. The initial appraisal and the programme of measures treat the two types of bodies of water separately. Overall, 30 of the 105 bodies of water are subject to over-abstraction and are classified as depleted, comprising 12 confined aquifers and 18 unconfined aquifers (see Figure 4. 4). Eleven of these bodies of water are classified as having a poor quantitative status because they were failing to supply sufficient water to the watercourses as a result of overexploitation. This approach illustrates how the SDAGE genuinely integrated surface and groundwater management. The analysis of the issues relating to confined aquifers was also more detailed in the 2010 version than previously. The state of the confined bodies of water (Figure 4. 5) are clearly identified on the basis of the better understanding obtained since the first SDAGE and with the use of large multi-layered groundwater models (Wuilleumier et al, 2016).

The 2010 SDAGE set extremely ambitious and fairly precise goals for groundwater: $95 \%$ of the 105 groundwater bodies (confined and unconfined) should achieve a good quantitative status by $2015,98 \%$ by 2021 and virtually $100 \%$ by 2027. It clearly identified five bodies of water (in the confined aquifer category) that would not be able to achieve a good status by 2015 . However, it was rather vague about how the targets would be achieved. The actions listed in the programme of measures were very general, for example "restore the balance between abstraction and recharge" or "limit the risk of saline intrusion". The SDAGE stated (provisions $\mathrm{C} 7$ and $\mathrm{E} 3$ ) that the problems of quantitative management would be resolved by implementing the new regulations resulting from the 2006 water law. The law stipulated that the volume to be abstracted should be calculated for each body of water and that the state should adjust the abstraction licences accordingly (see Chapter 3 ). The provisional cost of the measures linked to quantitative groundwater management was relatively low (63 million euros or $1.5 \%$ of the total cost of the programme of measures and 1.5 euros per inhabitant per year). 


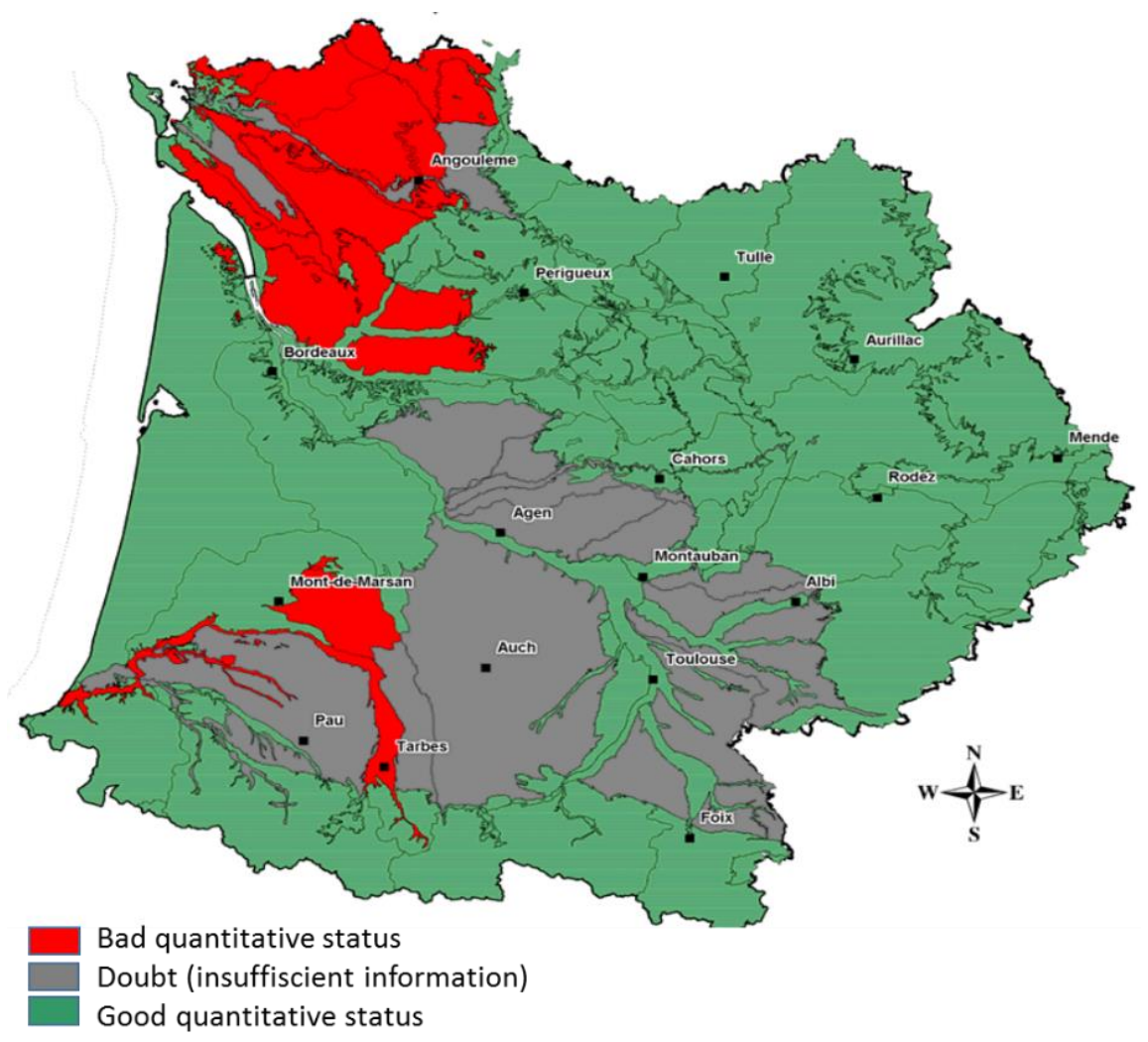

Figure 4. 4: Map showing the quantitative status of the unconfined groundwater bodies (SDAGE 2010-2015) 

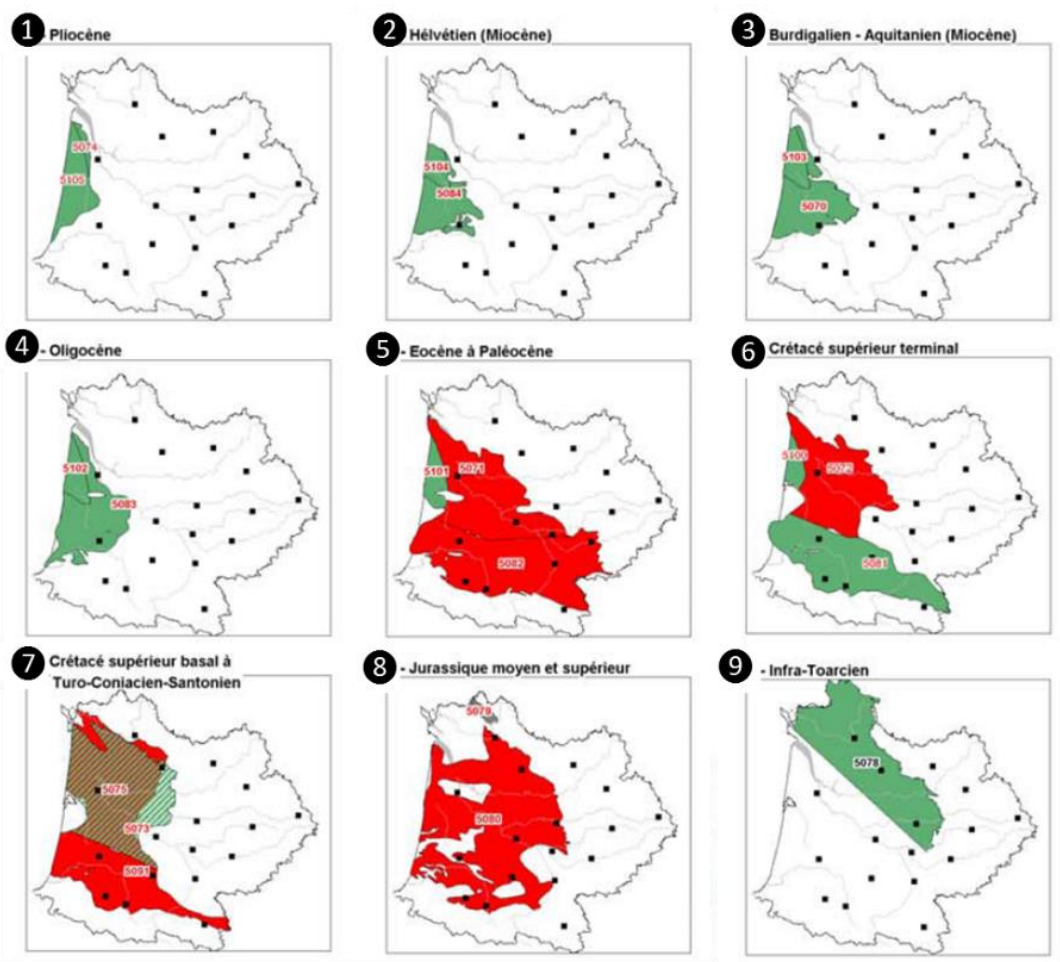

Bad quantitative status

Doubt (insuffiscient information)

Good quantitative status

Figure 4. 5: Map of the confined groundwater bodies showing their quantitative status (SDAGE 2010-2015). Numbers indicate the position of each aquifer layer in the geological sequence (9 is the deepest)

In early 2016, a new version of the SDAGE came into force after a second update involving stakeholders. Overall, it was an extension of the previous version but included more specific measures and practical details. Measure $\mathrm{C} 1$ relates to improving knowledge of the groundwater-river interactions and recommends that the SAGE should conduct studies to delineate the aquifers that interact with the watercourses and establish how the karstic aquifers function. Measure C5 specifies the methodology that can be used to identify the basins with a water deficit. One of the innovative elements of this SDAGE was its emphasis on taking climate change into account. In particular, it recommended conducting an assessment of the impact of climate change on the resources (measure A15) and the development of an adaptation plan (A16). In addition, it recommended conducting regional forecast exercises (A18 and A19) and taking into account the interactions between water and energy policies. 


\section{Groundwater management planning in the Loire-Bretagne Basin}

\subsection{The context leading up to the implementation of the SDAGE}

In the early 1990s, groundwater resources in the Loire-Bretagne Basin were already heavily exploited during dry periods, particularly for irrigation. After the summer and winter droughts of 1989-1992, this intensive use reduced baseflow discharge to streams during low-flow periods, causing certain watercourses to dry up. The drop in spring and summer groundwater levels also caused many springs to dry up completely, which severely affected certain wetlands, particularly, the Poitevin Marshes.

When work started on preparing the first SDAGE, the Loire-Bretagne Basin stakeholders were already aware of the specific challenges of groundwater management and the importance of the interactions between groundwater and surface water resources. Representatives from the agricultural sector were also convinced of the need to implement mechanisms to manage abstraction. The first Loire-Bretagne SDAGE was thus drafted in a more favourable political context than was the case for the Adour-Garonne SDAGE.

Pilot groundwater management experiments had already begun elsewhere, for example in Beauce, where an innovative quantitative management mechanism was introduced before the 1992 water law came into force (see Chapter 5). Piezometers had already been installed there to observe the change in the groundwater levels and restrictions of use were imposed when the level dropped below the alert thresholds. The principles of this pilot experiment were incorporated in the SDAGE and subsequently inspired the quantitative management systems introduced in many other river basins (see Chapter 18).

The stakeholders in the Loire-Bretagne Basin were also pioneers in terms of the regulatory framework for monitoring resources. In 1990, the agency's board of directors had already agreed to finance the creation of a groundwater level monitoring network which began in 1993. It was a gradual process with a goal of creating 30 monitoring sites in each county.

\subsection{Groundwater in the first SDAGE (1996)}

As far as groundwater was concerned, the SDAGE focused primarily on the need for preventive action to avoid the irreversible depletion of the groundwater resources. To achieve this, the SDAGE underlined the importance of improving the understanding of aquifers including the geometry and hydrodynamic characteristics, recharge rates and the interaction with watercourses. The SDAGE recommended conducting one-off campaigns to measure the groundwater levels until a 
denser groundwater monitoring network was in place. It also recommended conducting an inventory of the abstraction points, with details of the aquifers that are exploited and most importantly, the amount abstracted for irrigation (provisions VII-2-11 and VII-3-1). The goal was to provide the necessary information to develop groundwater flow models that the managers could use as a management tool where necessary.

One of the main contributions that the 1996 SDAGE made to the quantitative management of groundwater resources was to identify six major aquifers or catchment basins where abstraction exceeded the renewable resource (provision VIII-31, see Figure 4. 6). These were referred to as the intensely exploited aquifers. The SDAGE underlined the fact that greater effort was needed to improve our understanding and management of these intensely exploited zones and recommended applying rules to manage abstraction. The idea was that local stakeholders would develop rules within the framework of the SAGE. These locally defined rules would then be incorporated into the SDAGE to consolidate their regulatory status. The water agency integrated the zoning of intensively exploited aquifers into its grant policy, by awarding greater subsidies to all the studies and actions designed to improve the resource management in these zones.

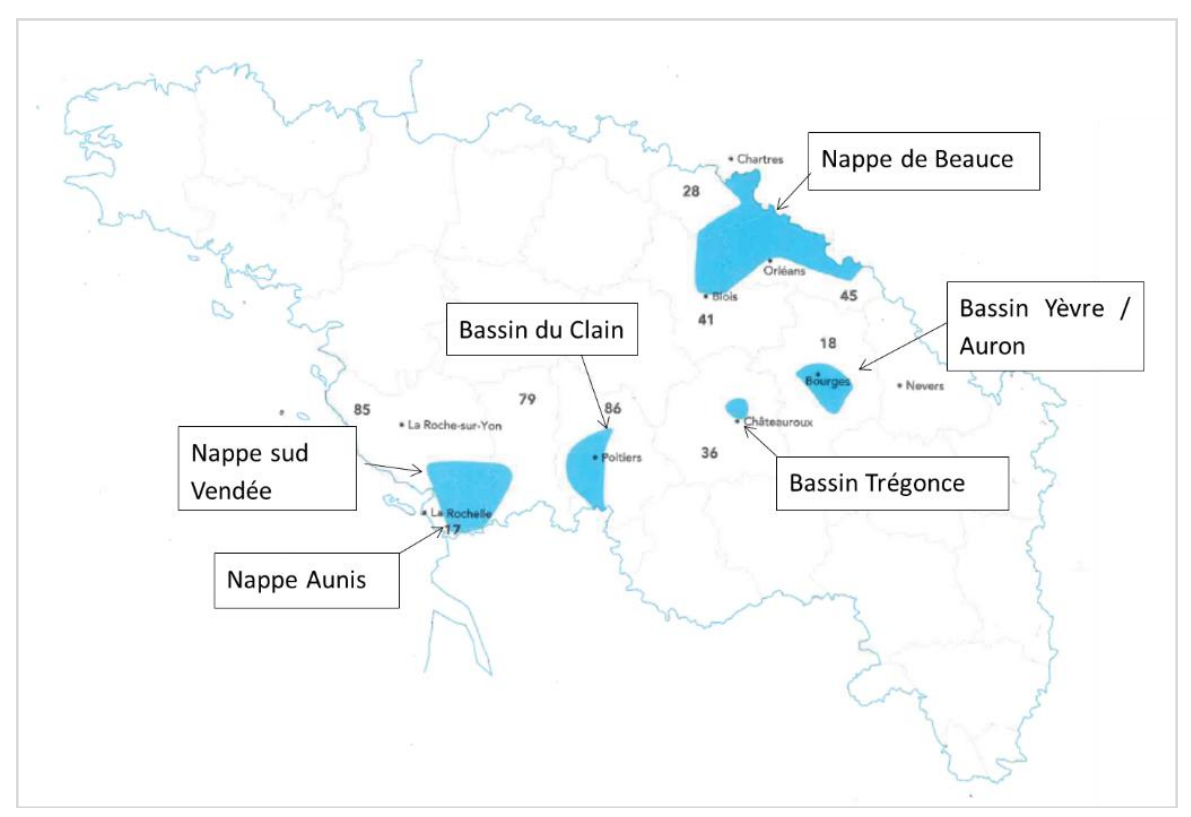

Figure 4. 6: Map of the intensively exploited aquifers. Source SDAGE 1996

As far as the management rules were concerned, provision VII-2-11 of the SDAGE states "the management objective is to reconcile the different uses in the best possible conditions and at the same time, ensure that the heritage is preserved 
[by maintaining] a minimum groundwater level". As in the case of the Adour-Garonne Basin, this involves defining the target groundwater threshold levels (TTL) and the crisis threshold levels (CTL) that would trigger restrictions of use. The reference to this management principle in the SDAGE (provision VII-3-1) specifies how the 1992 water law is applied. In this sense, the SDAGE defines the strategy to implement the law which was then be implemented by State agencies in several river basins (the Clain, Sèvre Niortaise and Yèvre Auron basins). The introduction of this management scheme actually took several years because of the time involved in setting up the groundwater monitoring networks, collecting data and conducting the necessary studies to identify the TTLs and TCLs. In the case of the Beauce region, the existence of a groundwater monitoring network since 1974 meant that a TTL level could be defined directly in the 1996 SDAGE (provision VIII-3-3).

The droughts made the requirement for management politically favourable and the first water meters were installed at agricultural abstraction sites in 1994. The agency subsidised their installations at a rate of $80 \%$, which facilitated their adoption especially in Beauce region. By 1999, almost $100 \%$ of the surface and groundwater abstraction points in the Loire-Bretagne Basin were equipped with a meter. The agricultural institutions supported the introduction of volumetric quotas for individual abstraction because they considered that the management model, although restrictive, would help reduce the frequency of crises and the associated bans on use. The volumetric management principle was made operational for the first time in Beauce in 1999. It is important to underline that in the remainder of the AdourGaronne Basin, representatives from the agricultural sector are still reluctant to accept the principle in 2018.

The 1996 SDAGE also identified the aquifers that should be reserved for the drinking water supply. The provision VIII-3-2 lists these aquifers, most of which are confined (Figure 4. 7). Although existing agricultural boreholes can be maintained, this SDAGE provision prevents the state services from issuing new abstraction licences for agricultural use. The application of this provision did not pose major difficulties because there are generally unconfined aquifers that can be used for irrigation above the reserved confined aquifers. The main target here was to preserve the good natural quality of these protected aquifers, by preventing the installation of works that could established undesired hydraulic connections between the polluted unconfined and good quality confined aquifers. 


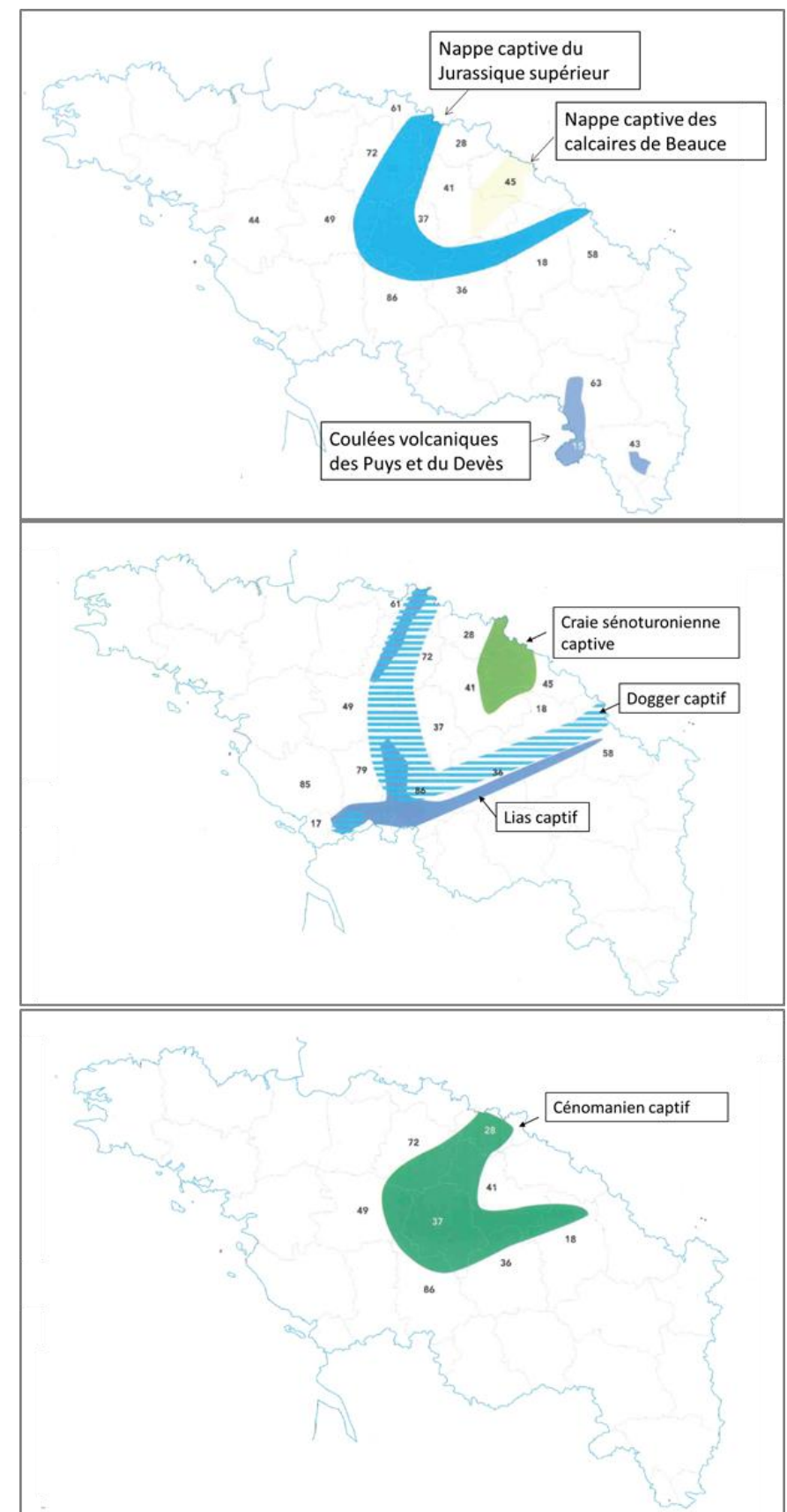

Figure 4. 7: Maps of the aquifers reserved for the drinking water supply-source SDAGE 1996 


\subsection{The revisions of the SDAGE from 2010 to 2016}

In 2003, all the aquifers that the SDAGE had identified as intensely exploited were decreed water restriction zones (Zones de Répartition des Eaux in French, Chapter 3) by the Council of State. Thus, the SDAGE facilitated the introduction of this regulatory tool which gave government agencies greater control over all abstraction. With the enforcement of the 2006 law on water and aquatic environments, a ministerial circular in 2008 requested that Sustainable Abstraction Limits (SAL) should be estimated (in annual volume) for all the aquifers under restriction. The SAL represents the maximum volume of water that can be abstracted annually for each body of water, without compromising its good ecological status (see Chapter 11). The SALs were defined on the basis of hydrogeological studies, which were supervised by the water agency if there was no SAGE in place. The SALs were included in the SAGE, which made them legally binding and enforceable. Henceforth, the state services that delivered abstraction licences had to ensure that the sum of individual allocations did not exceed the SAL. In most situations however, the current volumes actually abstracted considerably exceeded the SAL, which meant they had to be reduced significantly.

The Loire-Bretagne SDAGE was first updated in 2010 without significantly changing groundwater management policy priorities. As the first generation of problems had been tackled between 1996 and 2009, the SDAGE for the period 2010-2015 concentrated on new problem areas, where management rules had to be introduced to limit abstraction. Thus, the SDAGE identified the "basins that require greater protection during low-flow periods". This involved capping abstraction at 2009 levels and introducing water saving and conservation measures in the sectors of agriculture and urban water supply (measure 7A-1). The SDAGE also designated "basins where prevention was required to prevent the appearance of quantitative deficits", by capping annual abstraction at current levels (measure 7A-2). These provisions were to be confirmed in the 2016-2021 SDAGE (see Figure 4. 8), which includes additional zoning (7B-2) where a limited increase in abstraction is possible, which was specified in $\mathrm{m} 3$ per square kilometre. 


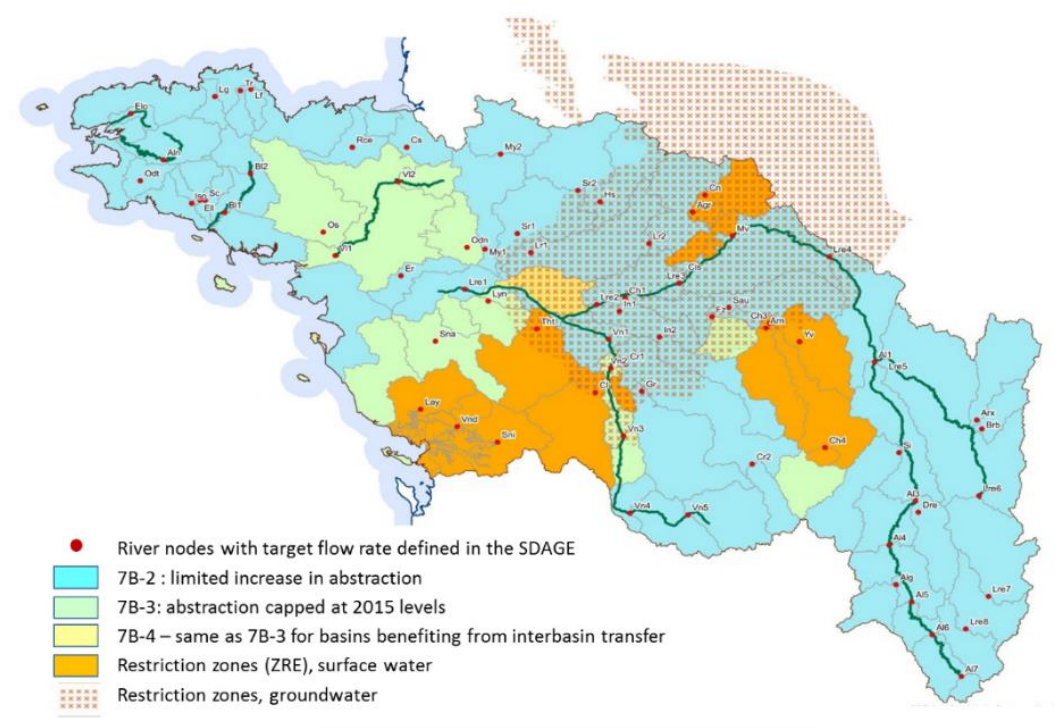

Figure 4. 8: Map of basins with a limited increase in abstraction at low water (7B2) and with abstraction capped at current levels (7B-3, 7B-4). SDAGE 2016-2021.

The SDAGE also sets out in detail how to implement its recommendations in three specific regions: the Beauce, the Poitevin Marshes and the Cenomanian Aquifer. In these basins, the state services and the water agency had already taken the initiative to introduce fairly elaborate local management rules. As the local stakeholders had not yet validated these rules in the framework of the SAGE, the SDAGE specified them to give them a legal status.

- The management rules for the Beauce Basin were specified in provision 7C-3, which sets the target and crisis groundwater threshold levels (TTL and CTL) as well as an intermediary Alert Threshold Level (ATL) at which restrictive measures should gradually be implemented. The measure also sets the volumes to be abstracted per economic sector (drinking water, irrigation and industry) and the restrictions applied to groundwater abstraction in the event of a reduction in the flow of watercourses receiving discharge from the aquifer.

- The Poitevin Marshes are also subject to a specific measure (7C-4), which sets out the management rules, particularly the details of the alert and crisis thresholds levels for water in the marshes and the aquifers. These rules are established in the SDAGE provisionally, until such time as they are specified in the SAGE. 
- Lastly, the management rules for the confined Cenomanian Aquifer are set out in provision 7C-5, which specifies the maximum volumes for abstraction per sector. These volumes were determined on the basis of the groundwater modelling study conducted by the water agency. Interestingly, local water users were reluctant to set up a SAGE because it was a complex process for a region covering $25000 \mathrm{~km}^{2}$.

After its second revision (2010-2015), the SDAGE included a framework to regulate new storage facilities that started to be constructed in the late 2000s. They consist in small to medium reservoirs (with capacities up to $800000 \mathrm{~m}^{3}$ ) which are filled with groundwater during winter when aquifer levels are high and then used for irrigation in summer, when there is a risk of groundwater use restriction. The SDAGE encourages the construction of such reservoirs in the basins classified as water restriction zones, under the conditions that users would totally cease pumping groundwater in summer and that they would use $20 \%$ less water from the reservoirs than they took from groundwater previously (measure 7D-1). In addition, the SDAGE states that an abstraction licence must be obtained to fill the reservoirs, and this licence must specify the groundwater level below which all abstraction for filling the reservoir is prohibited (measure 7D-2).

The third version of the SDAGE for the period 2016-2021 is a continuation of the first two versions. It underlines the need to adapt to climate change by recommending that the definition of target groundwater levels (measure 7A-1) should take climate change into account and if necessary, abstraction licences should be reviewed and reduced accordingly (7A-6). The measures 7A-3 to 7A-5 also highlight the importance of saving as much water as possible for the different uses. The introduction of water saving measures was clearly set as a prerequisite for the construction of new water reservoirs.

\section{Discussion}

In the two river basins studied in this chapter, the planning approach outlined by the SDAGE significantly contributed to the development of quantitative groundwater management. The SDAGE made it possible to specify operational approaches to implement the legal framework, taking into considerations specific characteristics of each basins and the aspirations of stakeholders. More precisely:

- The SDAGE helped identify aquifers where urgent action was required, such as the protection of confined aquifers or the implementation of rules controlling abstraction where sustainability was threatened. By doing so, it often triggered action when local water users did not have the capacity to initiate control measures.

- It contributed to an increase in the technical and scientific knowledge relating to aquifers and the groundwater flow systems. The little known 
zones were investigated and groundwater flow models were developed to understand and subsequently, manage the aquifers in the Adour-Garonne Basin that extended over tens of thousands of $\mathrm{km}^{2}$.

- It led to the establishment of targets for the flow rate in the major watercourses at low water levels, as well as the corresponding groundwater level thresholds for several aquifers in the river basins that have high connectivity with surface water.

- In regions considered a priority, it encouraged and imposed the development of local management plans (SAGE) which contained practical groundwater management rules.

- It also boosted efforts to ensure that groundwater monitoring was consistent throughout the region.

- Lastly, the SDAGE accelerated the process of making information on groundwater available to the public, notably through the groundwater management information systems (see Chapter 9 by Sharple).

The initial SDAGEs were not perfect and were progressively improved in the subsequent revisions:

- In the first SDAGE for the Adour-Garonne Basin, the implementation of the measures was limited because they were not sufficiently detailed, and time scales were not specified. Rules and recommendations were vague and the river basins where specific measures should have been applied, were not specified. In addition, no enforcement regime was planned. These shortcomings were corrected in subsequent versions.

- One of the SDAGE's goals was to provide a framework to coordinate and create collaboration between the different public organisations involved in the water sector (regions, counties, water agency, and towns). Observers who experienced this period have described how difficult it was for the participants to change their own planning strategies and integrate the SDAGE's goals into their action plans. The different branches within the water agency struggled to coordinate their actions because they had previously planned their programs independently. The collaboration which the SDAGE had hoped to develop, took a considerable amount of time to achieve.

- In the initial SDAGEs, very few TTLs and CTLs, and even fewer SALs were set, particularly in the Adour-Garonne Basin. This are several reasons for this omission. The concepts of TTL and CTL are difficult to apply to the confined aquifers (see Chapter 1 by Lapuyade), and the lack of hydrogeological expertise in the state services and water agencies resulted in difficulties in understanding how confined aquifers functioned. This lack of understanding made it difficult to convince the local stakeholders of the need for management intervention. The SDAGE acted as a catalyst for local action by giving local stakeholders the means to act if the political will exists. However, it had little impact if the political will was lacking. 
- The management of unconfined aquifers is still in its embryonic stage because the participants that develop and approve the SAGE (the local water commission and the state) lack expertise. Although measures are created, they are not necessarily enforced because the water police consider that surface water issues have a greater priority than groundwater issues (see Chapter 23). This situation is also due to the agricultural sector's hostility towards the introduction of groundwater management rules as farmers that are subject to severe restrictions for surface water use are keen to maintain the relative freedom they have to use unconfined aquifers, even though they are connected to the rivers.

- It is also highly likely that the imposed SALs are still too high in some cases. Under these circumstances, it is not possible to achieve the targets for groundwater levels and watercourse flow rates and consequently, it is not possible to attain the good status of the natural environment in both the river basins studied in this chapter.

\section{Conclusion}

In France, the development of management plans for the major river basins played an important role in the implementation of the water policy. First of all, the planning process allowed local government and user representatives to be involved in the implementation of the water policy. This participatory approach made it possible to take into account the specific hydrogeological, economic and socio-political characteristics of the regions concerned. It enhanced the legitimacy and acceptability of the measures introduced, as well as ensuring the participants' commitment when it came to implementing the decisions that they had helped to negotiate. Lastly, one of the SDAGE's strengths is that it is a regulatory document which is endorsed by the state and specifies the legal obligations for water users in a major river basin.

By identifying priority knowledge gaps, the SDAGEs have also helped ensure that the water agencies concentrate their funding in problematic regions or on appropriate issues. Without this process, it is likely that the SDAGEs would not have been effective. The SDAGE also led to the development of cooperation between public funding bodies (agency, state and local governments), who had not previously coordinated their policies.

The SDAGEs also facilitated the creation of local water management plans (SAGEs). By setting targets, the SDAGEs gave local stakeholders considerable freedom to draft the measures that were needed to achieve the targets. They also facilitated local actions by producing consistent scientific knowledge for the different regions and by helping to establish groundwater monitoring networks and create stakeholder consultative networks. 


\section{Acknowlegdments}

The authors warmly thank Steve Barnett, for his very detailed and useful comments on a previous version of this chapter.

\section{Références}

Barraqué B, Laigneau P. and Formiga-Johnsson R-M. (2018) The Rise and Fall of the French Agences de l'Eau: From German-Type Subsidiarität to State Control. Water Alternatives, Vol 4, Issue 3.

Buller H. (1996) Towards sustainable management: catchment planning in France and Britain. Land use Policy, 13 (4): 289-302.

Brugeron A., Schomburgk S., Chery L. (2013). WFD Groundwater Bodies: Consequences of the new national aquifer reference system BDLISA for their delineation in France WFD Groundwater Bodies. International Workshop on Groundwater Systems in Europe, Aug 2013, Berlin, Germany: https://hal-brgm.archives-ouver$\underline{\text { tes.fr/hal-01163584 }}$

EauFrance - The status of surface water and groundwater (2015): http://www.eaufrance.fr/IMG/pdf/evaluation_2010-2013_201506_EN.pdf

Comité de bassin Adour Garonne (1996). Schéma directeur d'aménagement et de gestion des eaux du bassin Adour-Garonne. Agence de l'Eau, Toulouse, France. 113 p. + ann.

Comité de bassin Adour Garonne (2009). Schéma directeur d'aménagement et de gestion des eaux du bassin Adour-Garonne 2010-2015. Agence de l'Eau, Toulouse, France. 144 p + ann.

Comité de bassin Adour Garonne (2015). Schéma directeur d'aménagement et de gestion des eaux du bassin Adour-Garonne 2016-2021. Agence de l'Eau, Toulouse, France. 281 p. + ann.

Comité de bassin Loire Bretagne (1996). Schéma directeur d'aménagement et de gestion des eaux du bassin Loire Bretagne. Agence de l'Eau, Orléans, France.

Comité de bassin Loire Bretagne (2009) Schéma directeur d'aménagement et de gestion des eaux du bassin Loire Bretagne 2010-2015. Agence de l'Eau, Orléans, France. 248 p.

Comité de bassin Loire Bretagne (2015) Schéma directeur d'aménagement et de gestion des eaux du bassin Loire Bretagne 2016-2021. Agence de l'Eau, Orléans, France. 355 p. Accessible at : http://www.eau-adour-garonne.fr/fr/programme-dintervention-de-l-agence/un-cadre-le-sdage/sdage-pdm-2016-2021.html 
Conseil Scientifique du comité de bassin Adour Garonne (1999) Avis sur le programme eaux souterraines de l'agence de l'eau Adour Garonne. Mai 1999, Toulouse, Agence de l'eau Adour Garonne. 10 p.

European Commission (2004). Common Implementation Strategy for the Water Framework Directive (2000/60/EC) - Groundwater body characterisation - Technical report on groundwater body characterisation issues (as discussed at the workshop of 13th October 2003), Final draft, 11 April 2004. https://circabc.europa.eu/sd/a/157c2240-b988-417b-9137-

a14e89db41d8/Groundwater\%20characterisation\%20report.pdf

Laurans, Y., Bouni, C., Courtecuisse, A., Dubien, I., \& Johannes, B. (2001). L'évaluation économique de la théorie à la pratique: l'expérience des SDAGE en France. Natures Sciences Sociétés, 9(2), 17-28.

Martin, Y. (1996). Rapport sur la gestion durable des eaux souterraines. Conseil Général des Mines. Ministry of Industry, Paris.

Ministère de l'Ecologie, du Développement Durable et de l'Énergie - MEDDE (2015). Guide DCE - Plan d'Action Opérationnel Territorialisé - Guide pour la déclinaison des programmes de mesures en plan d'action opérationnel territorialisé (PAOT). MEDDE, $\quad$ Paris. http://www.gesteau.fr/sites/default/files/20150716_guide_paot_v1_final.pdf

Piégay, H., Dupont, P., \& Faby, J. A. (2002). Questions of water resources management. Feedback on the implementation of the French SAGE and SDAGE plans (1992-2001). Water policy, 4(3), 239-262

Plaud, M. (1996). SDAGE et SAGE pour les eaux souterraines en Adour Garonne. La Houille Blanche, No. 3, 1996 ; pp. 57-60

Roche, P.-A., Guerber, F., Nicol, J.-P., \& Simoni, M.-L. (2016). Eau potable et assainissement: à quel prix ? (No. 10151-1) 561. Paris: CGEDD-IGA. Ministère de l'Environnement, de l'Energie et de la Mer, Ministère de l'Intérieur.

Wuilleumier, A., Saltel M., Douez O., Cabaret O. Abasq L, Pedron N (2016). A platform to harmonize the regional hydrodynamic models in the south-western part of France. IAH congress, Montpellier. https://www.cfh-aih.fr/images/DOCS/ 